\title{
ВИЩА ОСВІТА
}

HIGHER EDUCATION

\section{ЭКСПОРТ ОБРАЗОВАТЕЛЬНЫХ УСЛУГ В СВЕТЕ НАЦИОНАЛЬНОЙ СТРАТЕГИИ РАЗВИТИЯ ОБРАЗОВАНИЯ В УКРАИНЕ ДО 2021 ГОДА}

\begin{abstract}
Введение. На сегодняшний день Украина фактически является достаточно крупным экспортером образовательных услуг, ориентированным на широкий круг участников мирового рынка. По данным Министерства образования и науки Украины если в 2010 году было около 40 тыс. иностранцев, то сегодня уже 65 тыс. В ближайшее время эта цифра достигнет 70 тыс. человек [1]. Таким образом, доля Украины на общемировом экспортном рынке образовательных услуг по разным оценкам стабильно составляет около 1,3 \%.

Анализ последних исследований и публикаций. Наряду с уже ставшим очевидным стремлением к высоким технологиям как характерной чертой украинцев, страна обладает рядом преимуществ, позволяющим говорить о сохранении значительного образовательного потенциала в стране [2]. А действенные шаги по диверсификации языковой политики в области обучения иностранных граждан, предоставление вузам возможности проведения обучения среди иностранных студентов на иностранных языках, уже дало быстрый эффект по увеличению численности иностранных учащихся до рекордных.

В тоже время, негативные демографические показатели, нашедшие отражение в сфере образования, периодическая стагнация экономики и трудности с финансированием образования заставляют рассматривать экспорт образования как один из важнейших и актуальных факторов. Учитывать этот фактор необходимо не только в аспектах модернизации системы образования и потенциального источника финансирования преобразований, но и как важнейший и реальный источник поддержки образования и роста отечественной экономики [3].

Изложение основного материала. Необходимо отметить, что и со стороны Правительства Украины, в целом, и МОН Украины, в частности, а так же, со стороны университетов постоянно проявлялся активный интерес к тем направлениям деятельности в сфере образования, которые являются необходимыми и базовыми условиями для успешного осуществления экспорта образовательных услуг. Это выражается и в растущем числе межгосударственных соглашений в области образования, и в участии в многочисленных международных проектах на разных уровнях, и в активной позиции самих университетов в этом направлении. Если выстраивать цепочку из таких взаимосвязанных направлений, то базовым звеном является развитие между-
\end{abstract}

DOI: 10.15276/opu.1.43.2014.48 
народного сотрудничества в образовании и посредством образования. В качестве ключевых моментов такого развития можно выделить: сохранение устоявшегося экспорта образовательных услуг, продвижение интересов Украины в мире, программа содействия международному сотрудничеству. Результатом успешной реализаций этого базового звена является интернационализация образования сопоставимые образовательные программы, институты, технологии обучения и организации учебного процесса, документы, мобильность и т.д. Интернационализация, в свою очередь, позволяет формулировать целевую установку на развитие экспорта образовательных услуг на новом государственном уровне.

Однако, анализ законодательной и нормативной базы в сфере образования, а также основных концептуальных документов за годы независимости Украины показывает, что отношение непосредственно к экспорту образовательных услуг на государственном уровне выражалось, в лучшем случае, в позиции “как есть”, а зачастую, просто игнорировалось.

В свете очевидных шагов в сторону европейской интеграции в сфере предоставления образовательных услуг иностранным гражданам в существующей системе экспорта образовательных услуг необходимо отметить следующие проблемы:

— несовершенство и неэффективность иммиграционной политики в сфере пребывания иностранных студентов на территории Украины;

- отсутствие должного взаимодействия и координации между государственными институтами, обеспечивающими пребывание иностранных студентов на территории Украины: Министерством образования и науки, Министерством иностранных дел и посольствами Украины в странах-потребителях образовательных услуг, Пограничной службой Украины, МВД, СБУ, прокуратурой;

- отсутствие сбалансированной системы поддержки, стимуляции и контроля крупнейших вузов, занимающихся предоставлением образовательных услуг для иностранных граждан;

- отсутствие государственных стандартов в сфере обучения украинскому и русскому языкам как иностранным для различных уровней языковой подготовки;

- отсутствие целостной нормативной базы функционирования системы подготовительных факультетов для иностранных граждан;

- отсутствие надлежащего контроля качества образования на подготовительных факультетах для иностранных граждан со стороны соответствующих подразделений министерства. [4].

Результаты. С учетом изложенного в настоящее время, как никогда, назрела необходимость в выработке и реализации первоочередных шагов в направлении актуализации экспорта образовательных услуг. И одобренная Указом Президента Украины № 344/2013 “Национальная стратегия развития образования в Украине до 2021 года" [5] должна стать отправным документом для работы в этом направлении. Для этого, к закрепленным в Национальной стратегии целям, а именно, повышению уровня и доступности качественного образования для граждан Украины в соответствии с требованиями инновационного развития экономики, современных потребностей общества и каждого гражданина; обеспечению всестороннего гармоничного развития человека, как высшей ценности общества; необходима постановка ещё одной: сохранение $u$ укрепление позищий украинского образования на мировом рынке образовательных услуг.

Это, в свою очередь, должно определить дополнительное, к закрепленным в Национальной концепции, направление развития образования - усиление протекционизма на традиционном для Украины рынке экспорта образовательных услуг, и стимулирование и поддержка экспансии на новые рынки.

Как следствие, перед высшим образованием должны быть поставлены и дополнительные задачи:

- расширение взаимодействия с государственными органами стран традиционных потребителей образовательных услуг с целью выработки дифференцированных подходов: к восстановлению партнерских отношений со странами, ушедшими с рынка потребления украинского образования в последние десятилетия (например, Сирия, Иордания, Саудовская Аравия, Йемен и др.); к поддержанию тесных партнерских отношений со странами, остающимися традиционными потребителями (Китай, Вьетнам, Тунис, Гвинея, Нигерия); к развитию отношений со 
странами - потенциальными потребителями, для расширения географии рынка (бывшие страны СНГ, Турция, страны африканского континента);

- выделение обучения иностранных граждан в вузах Украины в отдельный субъект нормативно-правовой базы системы образования с учетом специфики с целью акцентирования внимания на проблематике со стороны заинтересованных в сфере предоставления образовательных услуг иностранным гражданам государственных институтов; формирования целостного подхода в обеспечении гибкости и мобильности образовательной системы для удовлетворения современных потребностей мирового рынка образовательных услуг.

Дополнительные цели, направления развития и задачи, которые ставятся перед высшим образованием в целом, определяют необходимость в обновлении нормативно-правовой базы:

- в разработке и утверждении государственных стандартов и программ обучения русскому и украинскому языкам как иностранным на всех уровнях языковой подготовки иностранных учащихся;

- в создании нормативно-правовой базы системы мониторинга качества предоставления образовательных услуг иностранным учащимся;

- в создании единого нормативно-правового комплекса мероприятий для поэтапного сопровождения всех субъектов, предоставляющих образовательные услуги иностранным гражданам с момента обращения иностранного гражданина в вуз Украины для получения приглашения на учебу, до мониторинга трудоустройства иностранного гражданина за рубежом после завершения обучения в Украине.

- в разработке системы стимулирования вузов Украины к расширению объемов предоставления экспортных образовательных услуг. [4]

В Национальной стратегии заявлено о необходимости модернизации сети учебных учреждений разных типов, реорганизации и кооперации с целью более эффективного использования материально-технических, кадровых, финансовых и управленческих ресурсов. При этом важно, чтобы высвобождаемые ресурсы были направлены на укрепление потенциала и инфраструктуры системы “образования на экспорт".

Что касается самой сферы экспорта образовательных услуг, как отдельного компонента системы образования Украины, то её целями прежде всего должны являться:

- поддержка эффективного участия страны в процессах развития образования в направлении европейской и общемировой интеграции;

- повышение качества и, как следствие, привлекательности и конкурентоспособности отечественной системы образования на общемировом рынке образовательных услуг;

- повышение доли экспорта образовательных услуг и привлечение дополнительных ресурсов в вузы Украины.

Направления развития в соответствии с поставленными целями экспорта образовательных услуг должны существенно коррелировать с направлениями развития образования, закрепленными в Национальной стратегии развития образования в Украине до 2021 года, и могут быть сформулированы следующим образом:

- активное использование международных подходов, правил и процедур в развитии отечественного высшего образования;

- подготовка национальных кадров в соответствии с приоритетами;

- поддержка и стимулирование участия вузов в международных проектах, таких как Болонский процесс, ассоциации европейских университетов, двухстороннее сотрудничество на уровне университетов;

— активная информационная поддержка вузов за рубежом;

- содействие в обеспечении комфортного пребывания иностранных граждан, получающих образование на территории Украины в рамках государственной миграционной политики.

Выводы. Без включения перечисленных целей, направлений и задач Национальная стратегия по сути нивелирует экспорт образовательных как важнейшую область образования в Украине. Разрешение этого вопроса может реализовываться различными способами: от внесения 
предложенных дополнений в утвержденную Национальную стратегию развития образования в Украине до 2021 года до разработки отдельной стратегии области экспорта образовательных услуг с привлечением всех заинтересованных участников рынка образования. Очевидно, что разработка отдельной стратегии это сложная и трудоемкая задача, которая, тем не менее, является актуальной и требует быстрой и эффективной реализации. А большой и позитивный опыт обучения иностранных граждан со всего мира, накопленный в прошлом; современный опыт глобальной реструктуризации системы обучения иностранных граждан в Украине за годы независимости; опыт соседних государств, таких как Польша и Россия в развитии экспорта образования; а также, развивающиеся процессы интеграции Украины в мировое пространство, при актуализации вопросов экспорта образовательных услуг в рамках Национальной стратегии развития образования в Украине до 2012 года позволяют надеяться на успешную реализацию образовательного потенциала страны в ближайшее десятилетие.

\section{Литература}

1. В МОН обещают 70 тысяч иностранных студентов [Электронный ресурс] / Osvita.ua. Изд-во "Плеяды”. - Режим доступа: http://ru.osvita.ua/vnz/38542/ (Дата обращения: 02.02.2014).

2. Денисенко, Н.П. Украина и Российская федерация: основные направления взаимодействия в сфере высшего образования [Электронный ресурс] / Н.П. Денисенко, С.В. Бреус. - Режим доступа: ukros.ru/wp-content/uploads/2014/01/Денисенко-Н.П.-Бреус1.doc (Дата обращения: 02.02.2014).

3. Булгар, В.В. 3 досвіду набору іноземних студентів на навчання до Одеського національного університету / В.В. Булгар, А.О. Савєльєв, В.С. Шобік // Актуальні питання організації навчання іноземних громадян у технічних вищих навчальних закладах України: матеріали конференції $26-$ 28 квітня 2012 р. - Тернопіль: ТНТУ ім. І. Пулюя. - 2012. - С. $26-29$.

4. Савельев, А.А. О разработке национальной стратегии развития образования в Украине в аспекте международного образовательного рынка / А.А. Савельев // Актуальні питання організації навчання іноземних громадян у технічних вищих навчальних закладах України: матеріали конференції $26-28$ квітня 2012 р. - Тернопіль: ТНТУ ім. І. Пулюя. - 2012. - С. $19-22$.

5. Про Національну стратегію розвитку освіти в Україні на період до 2021 року [Текст] : указ Президента України від 25 червня 2013 року № 344/2013 // Урядовий кур’єр. — 2013. — 4 липня. — С. 11.

\section{References}

1. V MON obeshchayut 70 tysyach inostrannykh studentov [In the Ministry of Education and Science they promise to have 70,000 foreign students education [Electronic resource]] / Osvita.ua. Publishing house "Pleyady". - Available at: http://ru.osvita.ua/vnz/38542/ (Access date: 02.02.2014).

2. Denisenko, N.P. Ukraina i Rossiyskaya federatsiya: osnovnye napravleniya vzaimodeystviya v sfere vysshego obrazovaniya [Ukraine and the Russian Federation: the main areas of cooperation in higher education [Electronic resource]] / N.P. Denisenko, S.V. Breus. - Available at: ukros.ru/wpcontent/uploads/2014/01/Денисенко-Н.П.-Бреус1.doc (Access date: 02.02.2014).

3. Bulhar, V.V. Z dosvidu naboru inozemnykh studentiv na navchannia do Odeskoho natsionalnoho universytetu [From the experience of recruitment of foreign students to study at the Odesa National University [Electronic resource]] / V.V. Bulhar, A.O. Savieliev, V.S. Shobik // Aktualni pytannia orhanizatsii navchannia inozemnykh hromadian u tekhnichnykh vyshchykh navchalnykh zakladakh Ukrainy: materialy konferentsii 26-28 kvitnia 2012 r. [Current Issues of Foreign Students' Training in Technical Higher Educational Establishments: Conference, April, 26-28, 2012] - Ternopil. - 2012. pp. $26-29$.

4. Savel'ev A.A. O razrabotke natsional'noy strategii razvitiya obrazovaniya $v$ Ukraine $\mathrm{v}$ aspekte mezhdunarodnogo obrazovatel'nogo rynka [On the development of the national strategy of education in Ukraine in terms of the international education market] / A.A. Savel'ev // Aktualni pytannia orhanizatsii navchannia inozemnykh hromadian u tekhnichnykh vyshchykh navchalnykh zakladakh Ukrainy: materialy konferentsii 26-28 kvitnia 2012 r. [Current Issues of Foreign Students' Training in Technical Higher Educational Establishments: Conference, April, 26-28, 2012] — Ternopil. — 2012. — pp. $19-22$. 
5. Pro Natsionalnu stratehiiu rozvytku osvity v Ukraini na period do 2021 roku [Tekst] : ukaz Prezydenta Ukrainy vid 25 chervnia 2013 roku \# 344/2013 [Policy concerning the development of education in Ukraine for the period till 2021 [Text]: Decree of the President of Ukraine of June 25, 2013 № 344/2013] // Uriadovyi kurier [Governmental Courier] — 2013. — 4th of July. — p. 11.

\section{AНОТАЦІЯ / АННОТАЦИЯ / ABSTRACT}

Г.О. Оборський, А.О. Савєльєв. Експорт освітніх послуг у світлі Національної стратегії розвитку освіти в Україні до 2021 року. Вища освіта України як традиційний експортер на світовому ринку освітніх послуг стикається останнім часом з цілою низкою внутрішніх проблем. В основному це складності в організації навчання іноземних громадян, а саме: в координації між державними інститутами, в системі стимулювання і підтримки університетів, в області імміграційної роботи, в області державних стандартів у викладанні мов навчання, в нормативній базі, в системі контролю якості освітніх послуг. Ефективне стимулювання і розвиток експорту освітніх послуг можливі лише при комплексному державному підході, основою якого повинна послужити загальнодержавна стратегія. Однак, схвалена в 2013 році “Національна стратегія розвитку освіти в Україні до 2021 року” не розглядає експорт освітніх послуг як найважливішу складову вищої освіти. У зв'язку з цим, запропоновано і сформульовано додаткові цілі, пов'язані з ними напрями розвитку, а також завдання, які повинні бути поставлені перед системою освіти України і служити стимулом для актуалізації експорту освітніх послуг з урахуванням його важливості в системі освіти.

Ключові слова: експорт освітніх послуг, вища освіта, міжнародне співробітництво, інтернаціоналізація освіти.

Г.А. Оборский, А.А. Савельев. Экспорт образовательных услуг в свете Национальной стратегии развития образования в Украине до 2021 года. Высшее образование Украины в качестве традиционного экспортера на мировом рынке образовательных услуг сталкивается в последнее время с целым рядом внутренних проблем. В основном, это сложности в организации обучения иностранных граждан, а именно, в координации между государственными институтами, в системе стимулирования и поддержки университетов, в области иммиграционной работы, в области государственных стандартов в преподавании языков обучения, в нормативной базе, в системе контроля качества образовательных услуг. Эффективное стимулирование и развитие экспорта образовательных услуг возможны лишь при комплексном государственном подходе, основой которому должна послужить общегосударственная стратегия. Однако, одобренная в 2013 году “Национальная стратегия развития образования в Украине до 2021 года" не рассматривает экспорт образовательных услуг как важнейшую составляющую высшего образования. В связи с этим, предложены и сформулированы дополнительные цели, связанные с ними направления развития, а также задачи, которые должны быть поставлены перед системой образования Украины и служить стимулом для актуализации экспорта образовательных услуг с учетом его важности в системе образования.

Ключевые слова: экспорт образовательных услуг, высшее образование, международное сотрудничество, интернационализация образования.

G.A. Oborsky, A.A. Savel'ev. Export of educational services in the context of the National Strategy for the Development of Education in Ukraine until 2021. Higher Education of Ukraine as a traditional exporter in the global education market faces lately a number of internal problems. Basically, it is the complexities of the organization of foreign students training, namely in the coordination between government institutions, in the system of encourage and support universities, in the field of immigration work, in the field of state standards in language teaching training, in the regulatory framework, in quality system of education services. Effective promotion and development of export of educational services are possible only with complex state approach, which should serve as the basis for a nationwide strategy. However, "National Strategy for the Development of Education in Ukraine until 2021" approved in 2013 does not consider export of education services as an essential component of higher education. In this regard, the authors proposed and formulated additional goals, related areas of development as well as tasks that must be assigned to the educational system of Ukraine and serve as an incentive to actualize of the educational services export with the view of its importance in the education system.

Keywords: export of educational services, higher education, international cooperation, internationalization of education.

Рецензент канд. техн. наук, проф. Одес. нац. политехн. ун-та Булгар В.В.

Поступила в редакцию 12 марта 2014 г. 